K A N D A I

\begin{tabular}{|l|l|l|}
\hline Volume 17 & No. 2, November 2021 & Halaman 217-240 \\
\hline
\end{tabular}

\title{
AKTIVITAS SASTRA DI UNIVERSITAS HALU OLEO (Literature Activity in Halu Oleo University)
}

\author{
Rahmawati, Heksa Biopsi Puji Hastuti, Syaifuddin, \& Mulyadi \\ Kantor Bahasa Sulawesi Tenggara \\ Jalan Haluoleo, Kompleks Bumi Praja Andounohu, Kendari, \\ Sulawesi Tenggara, Indonesia \\ Pos-el: rahmaalyra@gmail.com
}

(Diterima: 18 November 2020; Direvisi: 4 Juli 2021; Disetujui: 28 Juni 2021)

\begin{abstract}
This study aimed to describe the literary activities carried out at Halu Oleo University (UHO) Kendari in the perspective of the sociology of literature by Pierre Bourdieu. This research is a qualitative descriptive study. Research data were information about literary activities at UHO obtained through questionnaires, interviews, note-taking, and literature studies. The informants' answers from the interviews in the research instrument were recorded. Literature study was used to obtain as much data as possible from relevant books or writings. Data from interviews, recordings, and literature studies were described and then classified according to the research problem. The results showed that literary activities that are often held at UHO include various literary activities that were packaged in an activity. In it, various literary activities were carried out, such as the Gerbang Lastra (Lastra Gate), Pentas Arena (Arena Performances), Pekan Sastra (Literature Week), Hibah Sastra (Literature Grants), Lomba Seni dan Pameran Karya (Lensa) (Art Competitions and Work Exhibitions), and so on. Student organizations that often hold literary activities included the Studio Drama, FKIP UHO, Bengkel Sastra Indonesia (BSI, Indonesian Literature Workshop), Pekerja Puisi Sulawesi Tenggara (Eksis) (Southeast Sulawesi Poetry Worker), Laskar Sastra (Lastra), UK-Seni, Sanggar Katalis, Fista, Himpunan Mahasiswa Jurusan Pendidikan Bahasa Indonesia HMJJPBI (Indonesian Language Education Department Student Association), and Himpunan Mahasiswa Sastra Indonesia (HMSSI) (Indonesian Literature Student Association). Literary activities that were built were born from the correlation between habitus, arena, capital capital, social capital, cultural capital, and symbolic capital. In carrying out literary activities, event organizers are still often constrained by funding, training venues, and secretariat rooms. Funding constraints are overcome by using membership fees, charging competition participants, sponsors, or holding fundraising activities through bazaar activities.
\end{abstract}

Keywords: literature activities, campus, sociology of literature

\begin{abstract}
Abstrak
Penelitian ini bertujuan mendeskripsikan aktivitas sastra yang dilaksanakan di Universitas Halu Oleo (UHO) Kendari dalam perspektif sosiologi sastra Pierre Bourdieu. Penelitian ini merupakan penelitian deskriptif kualitatif. Data penelitian merupakan informasi mengenai aktivitas sastra di UHO yang diperoleh melalui teknik kuisioner, wawancara, pencatatan, dan studi pustaka. Jawaban informan dari hasil wawancara dalam instrumen penelitian dicatat. Studi pustaka digunakan untuk memperoleh data sebanyakbanyaknya dari buku-buku atau tulisan yang relevan. Data hasil wawancara, pencatatan, dan studi pustaka dideskripsikan kemudian diklasifikasi sesuai dengan permasalahan penelitian. Hasil penelitian menunjukkan bahwa aktivitas sastra yang sering diadakan di UHO meliputi berbagai kegiatan sastra yang dikemas dalam suatu kegiatan. Di dalamnya dilaksanakan berbagai aktivitas sastra, seperti Gerbang Lastra, Pentas Arena, Pekan Sastra, Hibah Sastra, Lomba Seni dan Pameran Karya (Lensa), dan sebagainya. Organisasi kemahasiswaan yang
\end{abstract}


kerap menggelar kegiatan sastra antara lain Studio Drama FKIP UHO, Bengkel Sastra Indonesia (BSI), Pekerja Puisi Sulawesi Tenggara (Eksis), Laskar Sastra (Lastra), UK-Seni, Sanggar Katalis, Fista, Himpunan Mahasiswa Jurusan Pendidikan Bahasa Indonesia HMJJPBI), dan Himpunan Mahasiswa Sastra Indonesia (HMSSI). Aktivitas sastra yang dibangun lahir dari adanya korelasi antara habitus, arena, modal kapital, modal sosial, modal budaya, dan modal simbolik. Dalam menjalankan aktivitas sastra, penyelenggara kegiatan masih sering terkendala dengan pendanaan, tempat latihan, dan ruang sekertariat. Kendala dana diatasi dengan menggunakan iuran anggota, mengenakan biaya pada peserta lomba, sponsor, atau mengadakan kegiatan pencarian dana melalui kegiatan bazar.

Kata-kata kunci: aktivitas sastra, kampus, sosiologi sastra

DOI: $10.26499 / j k . v 17 i 2.2978$

How to cite: Rahmawati, Hastuti, H. B. P., Syaifuddin, \& Mulyadi (2021). Aktivitas sastra di Universitas Halu Oleo. Kandai, 17(2), 217-240 (DOI: 10.26499/jk.v17i2.2978)

\section{PENDAHULUAN}

Aktivitas sastra merupakan salah satu ekstrakurikuler yang sering dilaksanakan di kampus, termasuk di Kampus Universitas Haluoleo (UHO) Kendari. Aktivitas sastra yang sering dilaksanakan itu dalam berbagai bentuk, seperti pementasan drama, pembacaan puisi, musikalisasi puisi, penulisan karya sastra, bedah buku sastra, seminar sastra, dan sebagainya. Di sini, Kampus Universitas Haluoleo menjadi arena bagi pergulatan aktivitas sastra yang dilakukan mahasiswa.

Mahasiswa sebagai insan muda cendekia memiliki idealisme yang pada praktiknya dapat mewujud dalam bentuk gerakan (Barlian, 2010). Keterlibatan mahasiswa dalam berbagai aktivitas ekstrakurikuler seperti aktivitas sastra menjadi alternatif gerakan idealisme mahasiswa. Beberapa manfaat yang dapat diperoleh dari aktivitas bersastra antara lain melatih kerja sama yang baik dalam organisasi atau kelompok; mengembangkan kecakapan sosial; menambah relasi atau pertemanan; mengembangkan tiap individu dalam hal daya kreasi, mengembangkan emosi yang sehat pada tiap diri pemain; menghilangkan sifat malu, gugup, tegang, dan rasa takut; belajar memberikan apresiasi kepada diri sendiri dan orang lain dalam kelompok; serta melatih kepemimpinan dan kerja keras.
Dalam sebuah pementasan drama, misalnya, semua peran memiliki fungsi berbeda-beda. Berbagai kemampuan atau kecakapan sosial seperti kemampuan memimpin, kemampuan membangun jejaring, kerja sama dengan orang lain itu penting dimiliki oleh seorang mahasiswa. Sebagai calon pemimpin di masa depan, berbagai kecakapan dan kompetensi harus mereka miliki. Seorang mahasiswa harus terus meningkatkan kompetensi dirinya dalam ranah akademik dan dalam aktivitas nonakademik di kampus.

Tulisan ini mengkaji aktivitas sastra di kampus dalam perspektif sosiologis, khususnya dalam pandangan Pierre Bourdieu tentang arena (sastra). Kampus menjadi ranah yang memperlihatkan dinamika sastra para pelakunya yang bertujuan mencapai prestasi sebaik mungkin juga untuk menancapkan pengaruh mereka. Kampus yang secara spesifik dihuni mahasiwa sebagai agen atau aktor membukakan dirinya sebagai ranah kontestasi aktivitas sastra. Di sinilah menarik dan pentingnya membahas aktivitas sastra dalam paradigma sosiologi sastra dengan salah satu konsep Bourdieu. Para agen atau aktor sastra akan menjalankan pengaruhnya yang merupakan representasi dari habitus yang mereka bawa. Pada pengoperasiannya, hal itu akan mengejewantah dalam bentuk penggunaan modal atau kapital, yakni 
modal budaya, modal ekonomi, modal sosial, dan modal simbolik.

Dalam membicarakan gairah aktivitas sastra di kampus-kampus di Kendari, dinamika itu terlihat dari berbagai aktivitas sastra yang digelar di kampus UHO. Aktivitas sastra yang talah berjalan tidak terlepas dari keberadaan komunitas sastra yang ada di kampus. Dalam rentang waktu 1993-2004 telah berdiri setidaknya 10 unit kegiatan mahasiswa sebagai komunitas yang giat menggelar berbagai aktivitas sastra.

Sayangnya, aktivitas sastra yang diadakan di kampus tidak terdokumentasi dengan baik sehingga menyulitkan memperoleh gambaran mengenai dinamika dan keghairahan pegiat sastra dari masa ke masa. Aktivitas sastra perlu dipublikasikan dan didokumentasi dengan baik. Dokumentasi dan publikasi yang baik akan berdampak pada ketersebaran informasi berbagai aktivitas yang semakin meluas. Ketersebaran informasi aktivitas sastra diharapkan dapat mendorong partisipasi berbagai pihak untuk berkontribusi, misalnya menjadi penonton, penikmat, kritikus, ataupun sponsor. Lebih lanjut, pendokumentasian suatu aktivitas sastra sangat diperlukan untuk mengetahui aktivitas sastra apa saja yang pernah dilakukan di kampus, siapa penyelenggara, dan pihak-pihak mana saja yang terbabit di dalamnya. Data ini menjadi rekam jejak yang bisa digunakan untuk menelusuri keghairahan aktivitas sastra di kampus dari masa ke masa. Selain itu, inventarisasi aktivitas sastra di kampus dapat menjadi bahan atau data dalam menyusun rencana pelaksanaan kerja sama aktivitas kesastraan dengan komunitas yang ada di kampus.

Publikasi ilmiah tentang aktivitas sastra di kampus di Kota Kendari masih terbatas. Salah satunya yang talah ada seperti penelitian yang dilakukan oleh (Hidayat, 2004). Dari penelitian itu diketahui bahwa Bengkel Seni Fisip Unhalu (Benfis) yang eksis merupakan komunitas yang kegiatannya berfokus pada puisi, yakni pelatihan menulis puisi, diskusi, aktivitas pergelaran puisi, serta penerbitan bulletin mingguan Sangia. Bengkel Seni Fisip (Benfis) Unhalu merumuskan tujuannya untuk mencari seniman-seniman muda yang berbakat dan profesional; menciptakan kaderkader yang bertanggung jawab; dan menciptakan organisator yang andal. Unit Kegiatan Seni Unhalu pun setiap tahun mengadakan Pekan Seni yang menggabungkan aktivitas pertandingan olah raga, seni dan perlombaan di bidang akademik. Dalam bidang sastra dan teater diadakan lomba baca puisi, baca cerpen, lomba mendongeng, dan pementasan drama. Lalu dengan pengaruhnya di luar kampus, disimpulkan bahwa keberadaan komunitas sastra di daerah Sulawesi Tenggara itu digagas atau digerakkan oleh (lulusan) mahasiswa yang pernah bergiat dalam komunitas seni di kampus. Keberadaan mahasiswa menjadi sangat menentukan di dalam menggerakkan komunitas yang mereka kelola.

Penelitian lain yang membahas aktivitas sastra ialah penelitian oleh Sofian (2017) yang menelisik lomba story telling yang dilaksanakan oleh mahasiswa Jurusan Bahasa Inggris FKIP UHO setiap tahun. Manfaat yang bisa diperoleh siswa yang mengikuti kegiatan tersebut di antaranya: mereka mengenal berbagai cerita rakyat; menjadi ajang untuk belajar berkompetisi; memperluas pemahaman lintas budaya; serta menjadi agen perwarisan cerita rakyat.

Tulisan lain terkait manfaat yang bisa diperoleh dengan melakukan apresiasi sastra ialah tulisan Rafida (2013) yang menyimpulkan bahwa manfaat kegiatan apresiasi sastra yaitu terdapatnya peningkatan positif yang cukup berarti bagi siswa SD di Tasikmalaya dalam pemahaman 
mengenai dunia sastra, bertambahnya kemampuan menulis puisi, dan peningkatan minat baca.

Salam \& Anwar (2015) juga lebih dalam menggali strategi dan legitimasi dalam peraihan modal simbolis di antara komunitas sastra yang banyak bermunculan di Yogyakarta dengan tiga komunitas sebagai sampel. Strategi yang berbeda-beda membuat ketiga komunitas sampel itu memiliki kadar legitimasi yang berbeda-beda pula. Sementara itu, Nilofar (2016) mengkaji kehidupan komunitas sastra di Kota Malang dengan mengambil komunitas Pelangi Sastra Malang (PSM) sebagai objeknya. Nilofar menyimpulkan, komunitas itu melakukan aktivitas sastra dalam bentuk seperti kenduri literasi, diskusi sastra, bedah buku, membaca puisi, menerbitkan antologi cerpen dan puisi dengan habitus berdiskusi sastra di kafe dan membaca puisi diiringi musik. Arena produksi kultural komunitas PSM meliputi media sosial, media massa, publikasi karya, dan pertunjukan.

Penelitian untuk memahami komunitas sastra di Indonesia juga dilakukan oleh Manuaba (2019) yang mencoba menguak lebih jauh peranan produk komunitas sastra dalam pembangunan karakter di Indonesia. Manuaba tiba pada empat poin simpulan. Pertama, regenereasi sastra cenderung hanya terjadi pada komunitas sastra yang eksis saja. Kedua, komunitas sastra yang eksis, tidak hanya memproduksi karya sastra, melainkan juga memproduksi karya-karya lain, serta aktivitas seni budaya kreatif lainnya. Ketiga, komunitas sastra yang eksis melahirkan sastrawan yang potensial menghasilkan karya-karya sastra berkualitas yang sarat kearifan lokal. Keempat, kearifan lokal masingmasing mereka itu direvitalisasi dalam produk karya. Selanjutnya, corak karya sastra itu potensial dimanfaatkan dalam pembangunan karakter.

Dengan berkaca pada penelitian terdahulu, sesungguhnya ranah penelitian mengenai aktivitas ataupun komunitas sastra itu laus. Namun, karena mengingat belum terdokumentasikannya aktivitas sastra di Kota Kendari, termasuk di kampus, penelitian kali ini dimaksudkan sebagai dokumentasi awal dengan mengangkat beberapa permasalahan: bagaimanakah pelaksanaan aktivitas sastra di kampus UHO (terkait jenis aktivitas sastra; siapa saja pihak penyelenggara; mana saja pihak-pihak yang terlibat; apa tujuan pelaksanaan aktivitas; bagaimana teknis pelaksanaan kegiatan); dan apa saja hambatan yang dihadapi dalam pelaksanaan aktivitas sastra.

Tujuan penelitian ialah mendata dan menginventarisasi aktivitas sastra yang pernah dilaksanakan di kampus Universitas Halu Oleo. Inventarisasi meliputi penyelenggara aktivitas, pihak yang terlibat, tujuan aktivitas, dan teknis pelaksanaan kegiatan, dan hambatan yang dihadapi.

Penelitian ini diharapkan menjadi data terkait informasi aktivitas sastra yang yang pernah dilaksanakan di kampus UHO Kendari. Selanjutnya, data tersebut dapat dimanfaatkan untuk: a) memberi konstribusi pengembangan ilmu yang berkaitan dengan pengelolaan aktivitas sastra di kampus; b) menjadi landasan pengembangan terhadap aktivitas sastra di sekolah; c) memberi sumbangan referensi bagi pengelolaan ekstrakurikuler sastra di kampus; d) sebagai bahan bagi pemangku kebijakan terkait dalam membangun kerja sama dengan komunitas sastra di kampus agar pelaksanaan aktivitas sastra bisa tetap berjalan. 


\section{LANDASAN TEORI}

\section{Sastra dan Fungsinya}

Wellek dan Warren (1993) mengatakan bahwa sastra itu suatu kegiatan kreatif karya seni. Manusia memanfaatkan karya sastra sebagai media untuk mengungkapkan perasaan, ide-ide, dan kritik sosial dengan memanfaatkan bahasa sebagai alat ungkap. Sejalan dengan itu, Teeuw (2015) menjelaskan definisi sastra dari segi bahasa-bahasa Barat, literature (Inggris), literatur (Jerman), litterature (Perancis), semuanya berasal dari bahasa Latin bermakna 'segala sesuatu yang tertulis'. Kata sastra dalam bahasa Indonesia berasal dari bahasa Sansekerta yang bermakna 'mengarahkan, mengajar, memberi petunjuk, dan instruksi'. Sementara itu, Quinn (dalam Sarumpaet, 2010) menjelaskan bahwa secara sederhana sastra adalah "tulisan yang khas, dengan pemanfaatan kata yang khas, tulisan yang beroperasi dengan cara khas dan menuntut pembacaan yang khas pula."

Mengenai fungsi sastra, Horatius dalam Wellek dan Warren (1993) bahwa sastra mengemban dua fungsi, yakni dulce et ulite atau menghibur dan bermanfaat. Keindahan dan imajinasi yang tersaji dalam sastra memberikan hiburan kepada penikmatnya. Sementara, nilai didaktis menjadi sarana dalam menyebarkan nilai-nilai kebaikan. Komunitas sastra menjadi salah satu wadah estetik kreatif dalam mengembangkan diri. Aktivitas sastra merupakan bagian dari kegiatan apresiasi sastra. Aktivitasnya tersebar dalam berbagi bentuk apresiasi mulai dari tingkat menggemari, menikmati, mereaksi, dan memproduksi. Aktivitas itu dapat menumbuhkan pemahaman, penghargaan, kepekaan pikiran kritis, dan kepekaan sosial.

\section{Kegiatan Ekstrakurikuler}

Kegiatan ekstrakurikuler di kampus merupakan wadah kreatif bagi mahasiswa untuk menyalurkan bakat dan minat. Ada beragam jenis ekstrakurilkuler di kampus yang bisa diikuti. Di dalamnya dilaksanakan berbagai kegiatan yang dilakukan di luar jam kuliah. Kegiatan itu memberi keleluasaan waktu dan memberikan kebebasan kepada mereka, terutama dalam menentukan jenis kegiatan yang sesuai dengan bakat dan minat mahasiswa. Hal ini senada dengan pernyataan Rohinah M. Noor, (2012) bahwa ekstrakurikuler merupakan kegiatan pendidikan di luar mata pelajaran dan pelayanan konseling untuk membantu peserta didik sesuai dengan kebutuhan, potensi, bakat, dan minat mereka melalui kegiatan yang secara khusus diselenggarakan oleh pendiddik dan atau tenaga kependidikan yang berkemampuan dan berwenang.

Di samping itu, menurut Sayotte (2010) kegiatan ekstrakurikuler merupakan upaya mempersiapkan mahasiswa untuk memiliki kemampuan intelektual, emosional, spiritual, dan sosial. Melalui pengembangan aspekaspek tersebut mereka diharapkan dapat menghadapi dan mengatasi berbagai perkembangan dan perubahan yang terjadi dalam lingkungan pada lingkup kecil dan terdekat, hingga lingkup lokal, regional, nasional, bahkan global. Secara umum manfaat yang bisa diperoleh dengan melibatkan diri dalam berbagai kegiatan ekstrakurikuler di antaranya: (a) membuka wawasan; (b) melatih untuk bergaul, bersosialisasi, dan bersosialisasi dengan orang lain; dan (c) menjadikan mahasiswa lebih kreatif, lebih berani tampil berekspresi, dan percaya diri.

Aktivitas sastra merupakan salah satu kegiatan ekstrakurikuler yang ada di kampus. Kegiatan dilaksanakan dalam berbagai bentuk kegiatan seperti menulis 
puisi, musikalisasi puisi, monolog, teaterikal, dan sebagainya. Kegiatan menulis puisi maupun menulis cerpen merupakan kegiatan kreatif yang bisa melatih untuk berfikir kreatif, berfikir runtut, serta menyajikan suatu pesan berdasarkan wawasan, pikiran, perasaan dan pengalaman. Sementara itu, keterlibatan dalam kegiatan musikalisasi puisi dapat memperkuat daya sentuh puisi melalui representasi musik, dan merangsang aspek emotif. Keterlibatan dalam kegiatan teater dapat menambah kepercayaan diri, melatih kemampuan menghafal, badan menjadi sehat dengan latihan fisik yang rutin, membantu menemukan jati diri, dan belajar bekerja sama dengan orang lain.

Aktivitas sastra di kampus ada yang dilaksanakan dalam bentuk perlombaan ada pula yang dilaksanakan dalam bentuk pementasan yang bertujuan untuk menghibur atau pengisi acara. Sebuah aktivitas lomba bermanfaat untuk melatih diri menghadapi persaingan sehingga dapat memacu diri untuk meningkatkan kompetensi. Berlatih untuk menjadi pengisi acara bermanfaat untuk membina kedisiplinan juga sekaligus mengembangkan kreativitas. Adapun aktivitas mengelola suatu kegiatan sastra dapat memberikan pengalaman dalam mengatur, dan menyelesaikan suatu persoalan.

\section{Sosiologi Sastra}

Sosiologi sastra merupakan pendekatan yang digunakan dalam penelitian ini. Sosiologi merupakan telaah yang obyektif dan ilmiah tentang masyarakat; telaah tentang lembaga dan proses sosial. Sosiologi mencoba mencari tahu bagaimana sastra dimungkinkan, bagaimana ia berlangsung, dan bagaimana ia tetap ada. Seperti halnya dengan sosiologi sastra berurusan dengan manusia dalam masyarakat; manusia berusaha menyesuaikan diri dan usahanya itu untuk mengubah masyarakatnya. Dengan demikian sosiologi dan sastra berbagi dengan masalah yang sama (Damono, 1979). Sebagai sebuah produk budaya karya sastra tidak bisa dipisahkan dari penulisnya sebagai anggota masyarakat. Ratna (Ratna, 2013) menjelaskan tugas sosiologi sastra baik sebagai institusi formal maupun literer menjadi lebih penting dalam kaitannya sebagai aset kebudayaan. Sastra eksis karena ada manusia yang menulisnya (penulis) dan penulis itu hidup dalam sistem sosial masyarakat yang menjadi objek kajian sosiologi. Dalam konteks ini, relasi sosiologi dengan sastra digambarkan sebagai berikut. Relasi sosiologi dengan sastra dimediasi oleh pengarang. Penulis karya sastra adalah individu yang hidup dalam konteks masyarakat. Oleh karena itu, pikiran dan perasaan yang ditulis dalam karya sastra selalu merepresentasikan pandanganpandangannya pada masyarakat tempat penulis itu eksis. Pandangan-pandangan penulis umumnya merepresentasikan keadaan sosial masyarakatnya. Hal ini terjadi karena manusia meruppakan makhluk bermasyarakat yang akan selalu melakukan proses internalisasi dan asimilasi terhadap nilai dan norma dalam masyarakat. Nilai-nilai yang menginternal dalam diri penulis sebagai bentukan dalam kehidupan bermasyarakat itulah yang selanjutnya muncul sebagai pandangan dunia dalam karya sastra.

Lebih lanjut, (Damono, 1979) menjelaskan beberapa klasifikasi masalah sosiologi sastra yang dikemukakan oleh beberapa penulis. (Wellek, 1993) mengemukakan tiga paradigma pendekatan dalam sosiologi sastra. Pertama, sosiologi pengarang. Inti dari analisis sosiologi pengarang ini adalah memaknai pengarang sebagai 
bagian dari masyarakat yang telah menciptakan karya sastra. Sosiologi pengarang berkaitan dengan ekonomi produksi sastra, latar belakang sosial, status pengarang, dan ideologi pengarang yang terlihat dari berbagai kegiatan pengarang. Pemahaman terhadap pengarang menjadi kunci utama dalam memahami relasi sosial karya sastra dengan masyarakat. Kedua, sosiologi karya sastra. Analisis sosiologi ini berangkat dari karya sastra, tujuan, serta hal-hal lain yang tersirat dalam karya sastra itu sendiri dan yang berkaitan dengan masalah sosial. Artinya, analisis terhadap aspek sosial dalam karya sastra dilakukan dalam rangka untuk memahami dan memaknai hubungannya dengan keadaan sosial masyarakat di luarnya. Ketiga, sosiologi pembaca. Kajian pada sosiologi pembaca ini mengarah pada dua hal, yaitu kajian pada sosiologi terhadap pembaca yang memaknai karya sastra dan kajian pada pengaruh sosial yang diciptakan karya sastra.

\section{Sosiologi Sastra Persfektif Bourdieu}

Produksi sastra merupakan salah satu arena perebutan pengaruh oleh para aktor atau agennya dalam mencapai tujuan untuk mencapai pengakuan, yaitu siapa yang akan dianggap sebagai pemilik salah satu posisi dalam area sastra tersebut. Oleh karena itu untuk mengungkap keterlibatan insan sastra dan seniman dalam melahirkan karyakarya mereka di Kampus Haluoleo penelitian ini menggunakan pendekatan sosiologi sastra dengan pendekatan dari konsep sosiologi dari Bourdieu tentang arena, yang dalam hal ini ialah arena sastra sebagai medan yang nyata dan tempat terjadinya perjuangan mencapai prestasi sastra dengan berbagai hubungan dan kaidah yang berlaku di dalamnya.
Arena (field, atau ranah) dalam pandangan Bourdieu berupa semesta atau lingkup sosial yang keberadaanya ialah nyata. Arena merupakan medan atau ranah yang di dalamnya terdapat seperangkat hukum aturan yang khas. Seiring dengan aturannya yang khas atau tertentu itu terdapat akumulasi bentuk kapital atau modal. Lalu di dalam arena itulah niscaya terjadi relasi adu kekuatan (Hartanto, 2011) berbagai agen ataupun individu dalam mencapai tujuan serta pengakuan sebagai paserta atau anggota dalam lingkup atau semesta sosial yang khas itu atau arena. Dengan kata lain, arena merupakan medan perjuangan bagi semua subjek guna menentukan siapa yang menjadi bagian dari semesta tersebut (misal siapa pengarang, sastrawan, aktivis yang sebenarnya dan siapa yang tidak. Arena merupakan sistem relasional atau di dalamnya terdapat berbagai kaitan antaragen sehingga dengan demikian berpikir dalam kerangka tersebut tidak lain merupakan bentuk berpikir yang bersifat relasional. Dalam kerangka arena, semua peristiwa yang berada dalam ranah politik, ekonomi, dan sosial lainnya akan selalu ditafsirkan kambali dalam logika arena secara khusus.

Sekaitan dengan arena, dalam Language and Symbolic Power (2007), Bourdieu memberi pengertian tentang ruang sosial. Ruang sosial itu ruang tempat berbagai dimensi yang di dalamnya terdapat prinsip perbedaan atau persebaran sekumpulan kepemilikan aktif (berbagai bentuk kekuatan atau kapital). Kepemilikan tersebut dalam ruang semesta pada gilirannya akan dapat memberi para penerus mereka itu kekuasaan. Posisi para agen dan kelompok agen akan menentukan kedudukan mereka sendiri berdasarkan posisi relatif mereka. Oleh akrena itu, kepemilikan berupa sumber daya atau kekuatan serta modal itu berguna untuk 
membangun ruang atau pun ruang itu digambarkan sebagai arena kuatan. Lalu, kepemilikan itu dimaksudkan sebagai properti aktif. Dengan demikian, properti aktif itu satu kumpulan hubungan kekuatan objektif yang ditentukan oleh mereka yang memasuki arena itu. Relasirelasi tidak dapat disederhankan sebagai niatan belaka oleh agen individu ataupun juga sebagai hubungan langsung antaragen (Bourdieu (2007) dalam Hartanto, 2011).

Bagi Bourdieu, di dalam arena kedudukan manusia tidak ditentukan oleh pengelompokkan berdasarkan kelas. Akan tetapi, kedudukan pribadi atau individu di dalam ruang sosial itu ditentukan oleh kepemilikan modal atau kapital dalam berbagai macam, terutama sebagai modal sosial, modal ekonomi, dan modal budaya. Semua aksi yang diambil manusia di dalam medan sosial merupakan arena guna meraih sumber daya. Menurut Bourdieu, produk budaya, termasuk sastra, merupakan sebuah medan tempat terjadinya perebutan posisi antarkelompok yang terdominasi dengan kelas yang dominan.

Di dalam arena perjuangan itu para agen memiliki bekal dengan perangkat yang paling utama, yaitu habitus dan modal (Hartanto, 2011). Habitus itu berada dalam pikiran aktor secara sadar, dan sebaliknya, arena berada di luar pikiran aktor. Dalam hal ini, arenalah yang membentuk pikiran aktor/agen. Bourdieu mendefinisikan habitus dalam "the acquired, the embodied, assimilated properties, such as elegance, ease of manner, beauty and so forth" (Bourdieu, 1993). Menurut Bourdieu, habitus adalah adanya bekal atau kepemilikan (properti) berupa sikap elegan, ketenangan pembawaan diri, kecantikan, dan sebagainya, yang diperoleh, dikandung, dan diasimilasikan (Bourdieu, 1993).

Tentang habitus Bourdieu itu, ia mengatakan habitus lahir secara spontan, tanpa sadar, dan tanpa batasan peraturan yang membatasi aksi agen. Yang membangun Habitus ialah untaian kecenderungan sehingga menggerakakn perilaku sosial agen dalam beraksi atau melakukan tindakan (aksi dan reaksi) secara khas. Dari situ timbullah kebiasaan praktik, persepsi, dan perilaku yang teratur tadi (Thompson, 2007 dalam Devi, 2010), "Habitus secara obyektif bersifat "teratur" dan "terlatih" tanpa merasa seperti diatur oleh aturan-aturan, seperti orkestra yang secara kolektif mampu berjalan harmonis tanpa merasa seperti diatur atau dipimpin oleh seorang konduktor" (Bourdieu, dalam Hartanto, 2011).

Selain habitus, perangkat penting bagi perjuangan dalam arena guna memperoleh posisi ialah kapital atau modal. Kapital itu ialah bekal yang diturunkan. Kapital yang demikian sangat kuat dapat menentukan berbagai peluang atau kemungkinan yang tidak dapat dipisahkan di dalam arena (Bourdieu, 1993:150, dalam (Hartanto, 2011). Menurut Bourdieu, kapital itu ada empat: kapital ekonomi (dapat berujud uang, properti, harta, dsb); kapital budaya (bisa berupa pengetahuan, pendidikan, keahlian); kapital sosial (berupa hubungan dan jaringan sosial); dan kapital simbolik (berupa legitimasi atau pengakuan dari pihak lain, reputasi, ketenaran, dsb). Dalam interaksi antarpelaku sosial dalam suatu arena, kapital merupakan kekuatan sosial atau properti aktif yang dijadikannya sebagai kekuatan (Hartanto, 2011).

Pengerahan atau dialektika habitus dan modal-modal itu di dalam arena yang khas itu merupakan ujud perjuangan dalam arena yang tidak lain melahirkan praktik. Praktik itu terbentuk dari berjalannya hubungan yang saling mendukung dan bersifat saling balas/dialektis antara sutruktur dan aktor/agen. Praktik yang terbentuk di 
dalam arena itu tidaklah dikendalikan oleh kehendak yang bebas yang bersifat berdiri sendiri, melainkan dari bentuk berjalannya hubungan antar-agen secara berkaitan. Di dalam peranan agen dan struktur, habitus dan arena merupakan kunci relasi di antara keduanya. Keduanya berkaitan atau berjalinan secara dialektis atau balas berbalas (Ritzer \& Goodman, 2005).

\section{METODE PENELITIAN}

Penelitian ini menggunakan metode deskriptif analitik dengan pendekatan kualitatif. Data yang diperoleh disusun, fakta-fakta dideskripsikan, dan selanjutnya dianalisis. Data tersebut meliputi jenis-jenis aktivitas sastra, waktu pelaksanaan, penyelenggara, kendala yang dihadapi di kampus. Data yang diperoleh merupakan hasil pengisian kuisioner dan hasil wawancara dengan pihak-pihak yang terlibat dalam aktivitas sastra seperti pegiat unit kegiatan seni, pemain, penulis, dan sebagainya.

Pengumpulan data dilakukan di Universitas Haluoleo (UHO). Di antara beberapa perguruan tinggi yang ada di Kendari, UHO termasuk perguruan tinggi yang paling aktif menyelenggarakan kegiatan sastra. Data itu berupa informasi tentang aktivitas sastra di kampus. Data diperoleh dari sumber tertulis dan sumber lisan. Sumber tertulis berupa laporan penelitian, buku, buletin, surat kabar, dan dokumen tertulis lainnya yang berkaitan dengan aktivitas sastra di kampus di Kota Kendari. Sumber lisan diperoleh dari informan yang mengetahui aktivitas sastra di kampus.

Pengumpulan data dilakukan dengan teknik wawancara terhadap para agen atau aktor dan studi pustaka. Teknik wawancara dilakukan dengan menggunakan pertanyaan-pertanyaan yang telah disusun sebagai instrumen penelitian. Informan penelitian adalah para pelaku unit aktivitas mahasiswa yang fokus pada aktivitas seni dan sastra dalam arena kesenian kampus Universitas Haluoleo. Status informan yang diwawancara beragam, ada yang sudah menjadi alumni dan ada pula yang masih menjadi mahasiswa.

Studi pustaka dilakukan untuk menjaring informasi dari berbagai literatur yang berkaitan dengan aktivitas sastra di kampus. Data yang sudah diperoleh dari hasil wawancara dan studi pustaka dikumpulkan dan diklasifikasikan sesuai dengan permasalahan penelitian. Penelitian pustaka juga dilakukan pada karya sastra hasil-hasil pelatihan penulisan yang dilakukan oleh unit aktivitas mahasiswa.

Untuk menguji keabsahan data yang sudah diperoleh dilakukan pengecekan kepada sumber data. Peneliti meminta keterangan kepada mereka yang pernah terlibat dalam aktivitas sastra di kampus (penyelenggara, pemain, panitia).

Teknis analisis data dilakukan dengan teknik analisis deskriptif kualitatif. Analisis data dilakukan dengan melalui tiga tahap, yakni reduksi data, penyajian data, dan tahap kesimpulan/verifikasi. Data yang diperoleh dari kuisioner dan hasil wawancara dirangkum untuk memilih data-data yang penting dan data yang tidak penting. Dengan reduksi, data yang diperlukan dalam penelitian terpilah dengan baik. Penyajian data dilakukan dalam bentuk uraian yang bersifat naratif. Teks naratif tersebut berisi uraian mengenai jenis aktivitas sastra, penyelenggara, waktu pelaksanaan, tujuan pelaksanaan, dan kendala yang dihadapi. Analisis data dalam paradigma diurai menggunakan pendekatan sosiologi sastra konsep arena (sastra) Pierre Bourdieu. Penarikan kesimpulan 
merupakan tahap akhir penelitian dalam menjawab rumusan masalah.

\section{PEMBAHASAN}

Pelaksanaan berbagai aktivitas sastra di kampus UHO dimotori oleh beberapa komunitas yang bergerak di dalam arena seni, sastra, dan budaya. Komunitas tersebut antara lain Studio Drama FKIP, Bengkel Sastra Indonesia (BSI), Eksis (Pekerja Puisi Sultra), Bengkel Seni Fisip (Bensfis), Laskar Sastra (Lastra), Unit Kegiatan Seni (UK Seni), Sanggar Katalis, Forum Insan Seni (Fista), HMJ Pendidikan Bahasa Indonesia FKIP UHO, Padepokan Seni Ekonomi (Pase), dan Sanggar Insan Seni (Sains). Komunitas-komunitas tersebut ada yang tergolong masih aktif menyelenggarakan berbagai aktivitas sastra, ada pula komunitas yang sudah vakum. Sekalipun sudah tidak aktif lagi, komunitas-komunitas dengan berbagai aktivitas yang sudah mereka gelar tetap dicatat dalam penelitian ini. Hal ini penting untuk melihat dinamika aktivitas di kampus. Di sini terlihat habitus sastra yang akan menjadi faktor determinan dalam membentuk dinamika kesenian di kampus.

Aktivitas sastra dilaksanakan dalam sebuah kegiatan yang multievent. Di dalamnya terselenggara juga aktivitas seni lainnya. Uraian mengenai pelaksanaan aktivitas sastra berikut diklasifikasi berdasarkan komunitas penyelenggara kegiatan, dalam persepektif sosiologi Bourdieu.

\section{Studio Drama}

Studio Drama FKIP UHO diprakarsai oleh Ahid Hidayat (Dosen FKIP UHO) pada tahun 2002. Studio Drama menjadi salah satu ruang sosial untuk mengkreasikan gagasan dan aktivitas sastra. Kepemimpinan Studio
Drama pernah pula dipegang oleh Laode Balawa, dosen FKIP UHO. Adapun beberapa aktivitas sastra yang pernah digelar di Studio Drama meliputi:

a) Pembacaan Cerpen, salah satu penampilnya adalah Al-Galih dan La Ode Balawa.

b) Pembacaan Puisi

c) Dialog Dua Ekspresi Sajak (Demo) yang menampilkan L. M. Saleh Hanan dan La Ode Balawa sebagai pembicara.

d) Pertunjukan teater.

e) Permorfance art.

\section{Bengkel Sastra Indonesia (BSI)}

BSI berdiri apda akhir Maret 1999 yang dimotori oleh mahasiswa Program Studi Bahasa dan Sastra Indonesia angkatan 1996, seperti Abdul Razak Abadi (Adhy Rical), Sumarlan Rasyid, Dedianto, dan Dhidit Marshel. Selain itu juga ada angkatan 1997 seperti Rusland Manan dan Syaifuddin Gani. Aktivitas sastra yang dilaksanakannnya antara lain:

a) Parade Pertunjukan "Mati Muda" dan "Marsinah Menggugat". Pentas "Mati Muda" adalah karya dan garapan Adhy Rical. Adapun "Marsinah Menggugat" merupakan karya Ratna Sarumpaet yang dimainkan Sendri Yakti.

b) Pementasan "Indonesia Koe (Kursi)"

Pementasan itu merupakan hasil garapan Achmad Zain. Drama dipentaskan pada bulan Februari 1999 di Pelataran Gedung D FKIP UHO.

c) Pementasan "Indonesia Masih Ada Kami”, digelar pada tanggal 15 Februari 2000 oleh Mahasiswa Bahasa dan Sastra Indonesia.

d) Pentas "Indonesia Jilid 2 (Refleksi Reformasi), ide cerita Achmad Zain, naskah/sutradara Adhy Rical, 22-25 Juli 2001 pada Festival Teater Mahasiswa Nasional 2001. 
e) Pentas "Sidang Para Setan" karya Joko Umbaran, sutradara: Adhy Rical, 7-8 Juli 2000 di Taman Budaya.

f) Pentas "M22" (Mati Muda Muda Mati) karya/sutradara Abd. Razak pada acara Temu Teater Mahasiswa Nusantara (Temu Taman), 21-28 April 2002 yang diselenggarakan oleh UKMSB, Universitas Muslim Indonesia, Makassar.

g) Pertunjukan "Mati Muda"

h) Penerbitan Buletin BSI

BSI menerbitkan Buletin BSI sebanyak tiga edisi. Buletin BSI memuat karya puisi, cerpen, dan esai. Melalui penerbitan Buletin BSI, tradisi menerbitkan buletin menjadi sebuah langkah yang penting di kampus. Para penulis, baik esai maupun sastra (cerpen dan puisi) mendapatkan ruang publikasi karya.

Pengerjaan Buletin BSI dilakukan di rumah pemimpin redaksi, yakni Abdul Razak Abadi yang sudah memiliki pengalaman di dunia jurnalisme karena pernah bergabung dengan sebuah surat kabar. Menariknya, para pengurus buletin tersebut juga berkhidmat di Teater Sendiri. Artinya, kerja literasi yang mereka lakukan di BSI memiliki hubungan kreatif dengan komunitas yang mereka terlibat di dalamnya.

\section{Pekerja Puisi Sultra (Eksis)}

Komunitas ini digagas oleh Irianto Ibrahim pada tahun 2001. Sekalipun sekretariatnya berada di luar kampus, tetapi anggota komunitas yang bergiat di dalamnya adalah mahasiswa dan dosen UHO. Komunitas ini fokus pada pelatihan membaca, menulis puisi, dan musikalisasi puisi. Selain itu, komunitas ini pun pernah menggelar lagi beberapa kegiatan yang pernah dilakukannya, antara lain pelatihan baca puisi, musikalisasi puisi yang digelar di kampus maupun Taman Budaya Sulawesi
Tenggara. Eksis pernah menerbitkan secara terbatas buku puisi Barzanji di Tengah Karang karya Irianto Ibrahim. Dua di antara beberapa anggota Eksis yang kini tetap bergiat di ranah seni ialah Wa Ode Nur Iman dan Syamsuddin yang kemudian hari masing-masing mendirikan Rumah Andakara dan Laskar Sastra. Komunitas tersebut tidak bertahan lama, tetapi kemudian bermertamorfosis menjadi komunitas baru, yakni Komunitas Arus yang juga didirikan Irianto Ibrahim.

\section{Bengkel Seni Fisip (Bensfis)}

Bensfis berdiri pada tahun 1986. Ketua I adalah Irfan dan Ketua II adalah Zainal. Bensfis menggelar berbagai kegiatan sastra, seperti pembacaan puisi dan pementasan. Data mengenai aktivitas sastra yang digelar di UHO tidak banyak yang bisa kami informasikan dalam penelitian ini. Selain sastra, mereka juga sering mengadakan pentas musik. Pementasan drama juga menjadi salah satu agenda pentingnya. Beberapa kali pentas drama Bensfis dilakukan, baik di kampus, maupun di luar kampus, seperti di Taman Budaya Sultra, Kolaka, dan Baubau. Sejak berdiri sampai saat ini, Bensfis menjadi salah satu komunitas seni kampus yang terus aktif, tidak hanya di ranah sastra, tetapi seni yang lain seperti musik dan tari.

\section{Sanggar Katalis}

Sanggar katalis merupakan sanggar seni yang ada di Fakultas Ilmu Budaya (FIB) UHO. Kegiatan yang pernah digelar oleh Sanggar Katalis antara lain pementasan dalam kegiatan Penjaringan Anggota Baru yang dilaksanakan pada tanggal 27 September 2017. Selain itu, Sanggar Katalis pun banyak menerima undangan untuk menjadi pengisi acara seperti: 
a) pengisi acara pada seminar kewirausahaan, 25 Desember 2017;

b) pengisi acara pada Festival Seni Budaya di Kolaka Timur;

c) pengisi acara pada kegiatan "Pentas Seni dan Budaya" (PASEBA);

d) berpartisipasi dalam kegiatan yang diselenggarakan oleh Program Studi Sastra Indonesia, Fakultas Ilmu Budaya, simposium Internasional Bahasa-Bahasa Lokal, nasional, dan Global, Oktober 2016;

e) menampilkan musikalisasi puisi dalam mengisi acara TRY OUT SBMNPTN 2016 di Gedung Sport Center UHO; dan

f) Kongres Nasional MAHASABHA $X$ yang merupakan kegiatan Mahasiswa Hindu Dharma Indonesia (KMHDI).

\section{Laskar Sastra (Lastra)}

Laskar Sastra adalah sebuah komunitas yang bergiat dalam bidang seni, sastra, dan budaya yang berada di FKIP UHO. Komunitas ini lahir pada tanggal 6 Juni 2006. Inisiatornya adalah mahasiswa Pendidikan Bahasa, Sastra Indonesia dan Daerah angkatan 2005 UHO. Visi komunitas ini adalah terbentuknya masyarakat kampus yang mencintai seni, sastra dan budaya dan selalu memegang nilai nilai intelektual. Logo Laskar Sastra bergambar lidah yang di dalamnya terdapat huruf "L" dan "S" yang membentuk huruf Qaf. Lidah menyimbolkan bahwa anak Lastra satu rasa. Huruf LS singkatan dari Laskar Sastra. Huruf "Qaf" memiliki arti bahwa anggota Laskar Sastra hendaknya selalu ingat akan kebaikan seperti dalam Islam jika menyebut satu huruf saja (salah satunya huruf Qaf) maka satu kebaikan yang kita dapatkan. Masih pada Simbol huruf "L" dan "S" yang bagian bawahnya meruncing seperti mata pena memiliki arti bahwa anggota Laskar Sastra hendaknya dapat berkarya sebagaimana pena menyimbolkan sebuah karya tertulis. Makna penggunaan warna hitam diartikan sebagai warna intelektual. Warna merah diartikan sebagai anggota Laskar Sastra yang selalu bergenggaman dan akan selalu berkarya. Warna putih melambangkan kesucian. Perekrutan anggota Angkatan 1 Lastra berlangsung pada tahun 2007. Selanjutnya, setiap tahunnya Lastra bergerilya untuk merekrut anggota.

Lastra termasuk komunitas yang aktif menggelar berbagai kegiatan sastra. Selain menggelar aktivitas di kampus, Lastra juga menerima kunjungan siswa yang mau belajar sastra, seperti penerimaan kunjungan dari Sekolah Dasar IT Al-Qalam dan juga adik-adik dari SMA DDI Kendari. Selain itu, Lastra juga bergerak pada kegiatan pembinaan seperti membina siswa MTsN 1 Kendari bermain drama.

Terkait dengan aktivitas sastra yang digelar oleh Lastra, ada kegiatan yang sudah menjadi agenda tahunan, ada pula kegiatan temporal yang digelar dalam rangka memperingati peristiwa tertentu, seperti peringatan Hari Pahlawan, Hari Pendidikan Nasional, dan sebagainya. Aktivitas yang menjadi agenda rutin Lastra ialah Gerbang Lastra dan Pentas Arena. Kegiatan temporal yang dilaksanakan adalah antara lain seperti kegiatan untuk merespon secara rutin, mengadakan berbagai kegiatan seni dan sastra melalui kegiatan berbagai kegiatan, seperti Gerbang Lastra, Pentas Arena, dan Pekan Sastra.

\section{Gerbang Laskar Sastra}

Gerbang Lastra menjadi ajang kompetisi tahunan yang digelar untuk memberi ruang kreatif bagi anggota Lastra. Awal mulanya Gerbang Lastra adalah kegiatan-kegiatan sederhana berupa pertunjukan-pertunjukan teater, pembacaan puisi, musikalisasi puisi, teatrikal, tarian dan drama. Namun, 
seiring berjalannya waktu, konsumsi pertunjukan seni mulai banyak diminati masyarakat khususnya mahasiswa. Laskar Sastra lewat program kegiatan Gerbang Lastra berusaha berbuat sesuai kemampuan untuk memenuhi kebutuhan kebutuhan seni masyarakat. Gerbang Lastra dari tahun ke tahun berusaha berbenah diri, meningkatkan kemampuan keterampilan yang dimilikinya.

Gerbang Lastra pertama kali dilaksanakan pada tahun 2012 dan sampai tahun 2019 ini Gerbang Lastra sudah memasuki pelaksanaan Gerbang Lastra yang ke-8. Pelaksanaan Gerbang Lastra setiap tahunnya digelar dengan tema yang berbeda-beda. Gerbang Lastra 5 yang digelar pada tanggal 17 Desember 2016 dengan tema "Lokalitas Budaya, Loyalitas Bersastra". Berbagai kegiatan digelar dalam Gerbang Sastra 6 ini, seperti seminar nasional, lomba baca puisi tingkat umum, dan lomba mendongeng tingkat SD. Penampilan teatrikal, pembacaan puisi, dan musikalisasi puisi oleh anggota Laskar Sastra ditampilkan sebagai acara hiburan. Dalam pelaksanaan lomba, peserta membayar kontribusi.

Seminar Budaya yang dilaksanakan dalam rangka Gerbang Lastra 6 bertema "Peran Budaya di Era Masyarakat Ekonomi ASEAN". Pemateri yang hadir Prof Dr, Nurhayati Bizzy, M.Pd. (Guru Besar Bidang Pendidikan Bahasa dan Sastra, FKIP Unsri, Palembang, Sumatera Selatan), Aris Badara, M.Pd., dan Dr. Sumiman Udu, M.Hum.

Gerbang Lastra 6 dilaksanakan pada tanggal 14-23 Oktober 2017. Seminar dan berbagai perlombaan digelar dalam momentum tersebut. Ada lomba tari yang diikuti oleh siswa SMA se-Kota Kendari. Ada pula lomba menulis yang diperuntukkan bagi siswa TK-SMA. Salah satu tujuan pelaksanaan kegiatan adalah melestarikan sastra dan budaya daerah. Kegiatan seminar yang dilaksanakan dalam Gerbang Sastra 6 mengangkat tema "Peran Sastra dalam Perkembangan Peserta Didik. Pendanaan kegiatan diperoleh dari iuran swadaya anggota Lastra, kerja sama sponsor, dan penjualan tiket.

Selanjutnya, Gerbang Lastra 7 berlangsung pada tanggal 9 November 2018. Kegiatan Gerbang Lastra 7 mengusung tema "Beragam Corak Budaya dan Sastra Ideologi Berkarya". Dua acara inti yang digelar dalam Gerbang Lastra 7 ialah seminar nasional dengan tema "Kebangkitan Kesastraan Sulawesi Tenggara" dan kompetesi seni lomba seni. Cabang seni yang diperlombakan terdiri atas lima tangkai lomba dan dua kategori. Adapun lomba tersebut, yaitu Lomba Cipta Puisi Tingkat Nasional, Lomba Cipta Cerpen Tingkat Nasional, Lomba Baca Puisi Tingkat Umum se-Sulawesi Tenggara (putra dan putri), Lomba Musikalisasi Puisi Tingkat Umum se-Sulawesi Tenggara, dan Lomba Tari Kreasi Tingkat Umum seSulawesi Tenggara. Lomba Baca Puisi Gerbang Lastra 7. Pemenang lomba baca puisi tingkat SMA adalah Femi Laurens (SMAN 1 Kendari) (Juara 1), Zahwa Diah A.P (SMAN 6 Kendari) (Juara 2), dan Heni Ardagarini (Pendidikan Bahasa Indonesia UHO) (Juara 3).

Seminar nasional dalam acara Gerbang Laskar 7 mengusung tema "Kebangkitan Kesastraan Sulawesi Tenggara. Pembicara dalam seminar tersebut antara lain Aslan Abidin (penyair dari kota Makassar, Sulawesi Selatan juga sebagai dosen Fakultas Bahasa dan Sastra Universitas Negeri Makassar), Irianto Ibrahim (penyair dari Sulawesi Tenggara juga dikenal sebagai seorang dosen Fakultas Ilmu Budaya Universitas Halu Oleo), dan Syaifuddin Gani (penggerak atau pengamat kesenian dan kebudayaan yang juga sebagai peneliti di Kantor Bahasa Sulawesi Tenggara). Adapun moderator pada seminar tersebut 
adalah Kahar Mappasomba, pemilik dari Rumah Bunyi yang merupakan toko dan penerbit buku. Gerbang Lastra 7 dilaksanakan pada tanggal 3-10 November 2018 yang berlangsung di Auditorium Mokodompit UHO, Aula FKIP UHO, Kantor Bahasa, dan Studio drama FKIP UHO. Peserta Kegiatan Peserta kegiatan ini adalah pelajar, mahasiswa, birokrasi kampus, dosen, dan pegiat seni se-Sulawesi Tenggara serta masyarakat umum.

Selanjutnya, Gerbang Lastra 8 dilaksanakan pada 23-30 November 2019 mengusung tema "Peran Sastra dalam Menghadapi Revolusi Industri 4.0". Untuk mendukung pelaksanaan lomba, peserta Lomba Baca Puisi dikenai biaya Rp50.000,00 dan untuk lomba menulis esai dikenai biaya pendaftaran juga sebesar Rp50.000,00. Peserta kegiatan ini adalah siswa SMA dan mahasiswa.

Sebagaimana pada pelaksanaan Gerbang Sastra sebelumnya, seminar sastra pun kembali digelar dalam Gerbang Lastra 8 dengan tema seminar "Membangun Generasi Melek Sastra di Era Milenial". Seminar yang berlangsung pada hari Sabtu, 23 November 2019 di Auditorium Mokodompit UHO, pukul 08.00 - selesai menampilkan tiga orang pembicara, yakni Tia Setiadi (Penulis dan Direktur Penerbit Citra Jogyakarta, Drs. La Ode Balawa, M.Hum. (dosen FKIP UHO), dan M. Ridwan Badallah, S.Pd., M.M. (Kepala Bidang Sosial Budaya Balitbang Sultra).

Laskar Sastra (Lastra) menjadi sebuah komunitas kampus yang benarbenar berbasis karya. Dari sastra, kita mengenal penyair Sulawesi Tenggara yang lahir dari Lastra, seperti La Ode Muhammad Rauf Alimin, Salim Kramat Alveronzo, Vicka Faulia, Ahmad Ridwan Wanderer, Muhammad Nadzir, Nardin Ace Effendi, dan Mashun Low. Pada tahun 2018 sebuah antologi puisi Tak Ada
Mata (Hari) karya 15 anggota Lastra terbit (Penerbit Rumah Bunyi).

\section{Pentas Arena}

Pementasan Seni dan Sastra (Pentas Arena) pun merupakan salah satu kegiatan tahunan yang dilaksanakan oleh Laskar Sastra. Pentas Arena dimaksudkan sebagai kegiatan penyambutan anggota baru Laskar Sastra. Selain itu, kegiatan ini menjadi ajang pembuktian kreativitas pecinta sastra, tantangan uji kemampuan untuk anggota yang baru saja menyelesaiakan tahap kaderisasi I anggota Laskar Sastra. Kegiatan yang dilaksanakan di pelataran FKIP UHO tersebut bertujuan untuk (1) memperkenalkan Laskar Sastra kepada mahasiswa UHO; (2) menunjukkan kreativitas anggota baru) kepada khalayak ramai; dan (3) memperkenalkan seni dan sastra kepada mahasiswa UHO.

Pentas Arena 8 merupakan salah satu Pentas Arena yang menampilkan Persembahan Puisi "Sajak Orang Gila" karya Muh. Ali Isbar. Pentas Arena 8 dilaksanakan pada tanggal 30 September 2016. Keseluruhan pementasan tersebut dipentaskan oleh anggota Lastra Angkatan 8, sebagai anggota yang baru saja bergabung dalam keluarga besar Laskar Sastra. Pembacaan Puisi dan Parade Puisi "Sebatang Lisong" karya W.S. Rendra dilaksanakan pada tanggal 08 Mei 2017. Selain pembacaan puisi, digelar pula kegiatan lain seperti aksi teatrikal, tari, dan musikalisasi puisi.

Pentas Arena merupakan kegiatan tahunan Laskar Sastra untuk menyambut angkatan baru Laskar Sastra, sekaligus ajang pembuktian kreativitas pecinta sastra, tantangan uji kemampuan untuk anggota yang baru saja menyelesaiakan tahap kaderisasi I anggota Laskar Sastra. Keseluruhan pementasan tersebut dipentaskan oleh angkatan 8, sebagai anggota yang baru saja bergabung dalam 
keluarga besar Laskar Sastra. Kegiatan ini dilaksanakan di pelataran FKIP UHO.

Selanjutnya, Pentas Arena 9 Laskar Sastra dilaksanakan pada tanggal 08 Mei 2017. Sama dengan yang sebelumnya, kegiatan ini mempersembahkan pembacaan puisi, seni teaterikal, tari, dan musikalisasi puisi. Pentas Arena ini juga merupakan kegiatan tahunan Laskar Sastra untuk menyambut angkatan baru Laskar Sastra, sekaligus ajang pembuktian kreativitas pecinta sastra, tantangan uji kemampuan untuk anggota yang baru saja menyelesaikan tahap Kaderisasi I anggota Laskar Sastra. Keseluruhan pementasan tersebut dipentaskan oleh angkatan 9, sebagai anggota yang baru saja bergabung dalam keluarga besar Laskar Sastra.

Pentas Arena X digelar pada hari Kamis, 3 Mei 2018. Menampilkan empat item pertunjukan, yakni pembacaan puisi, musikalisasi puisi, dan unjuk teaterikal. Pelaksanaan pementasan mengusung tema tradisional. Ada tiga tarian ("Selayang Pandang", "Lariangi", dan "Lulo Kreasi". Parade pembacaan puisi menampilkan 20 puisi, empat tampilan musikalisasi puisi, yakni "Hujan Menegur", "Perjalanan Kubur", "Padamu Jua", "Kelopak Mawar", Seni teaterikal berjudul "Andromeda" dan "Putri Alam".

Pentas Arena 11 Lastra digelar pada tanggal 2 Mei 2019 yang bertempat di Pelataran FKIP UHO. Kegiatan yang diisi dengan pementasan seni dan sastra itu juga bertujuan untuk memperkenalkan Laskar Sastra kepada mahasiswa UHO dan menunjukkan kreativitas anggota baru (Pentas 11) kepada khalayak serta untuk memperkenalkan seni dan sastra kepada mahasiswa UHO. Peserta yang terlibat dalam kegiatan adalah seluruh Anggota Pentas 11. Sebagaimana dengan pelaksanaan kegiatan-kegiatan Lastra sebelumnya, dana untuk pelaksanaan kegiatan Lastra berasal dari kas Lastra dan juga bantuan dari sponsor. Pelaksana
Pentas Arena 11 adalah pengurus periode $\mathrm{X}$ dan juga anggota Lastra Pentas 9 dan Pentas 10.

\section{Himpunan Mahasiswa Sastra Indonesia (HMSI)}

Himpunan Mahasiswa Sastra Indonesia (HMSI) berada di bawah Fakultas Ilmu Budaya UHO juga aktif menggelar aktivitas sastra di lingkungan kampus, seperti pentas drama dalam acara buka puasa bersama tahun 2016, pagelaran sastra angkatan 2013 yang dilaksanakan tahun 2016 (pembacaan puisi, drama, musikalisasi puisi).

\section{Pergelaran Sastra (2016)}

Pagelaran Sastra 2016 dilaksanakan di Aula Fakutas Ilmu Budaya UHO oleh mahasiswa Sastra Indonesia angkatan 2013. Kegiatan ini menampilkan pembacaan puisi, drama, dan musikalisasi puisi yang terbagi dalam beberapa kelompok. Kelompok Parade Puisi yang terdiri atas Inton Sarlis, Mohammad Haerun, Anis, La Ode Ali Akbar, Nurdahlia, Desi Ratna Sari, Iman Cahiya Angraini, dan Fitri Lamande tampil membaca puisi La Ode Balawa berjudul "Anak Sulawesi".

\section{Konser Sastra}

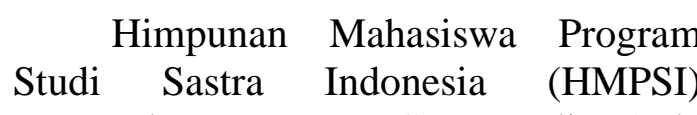
menggelar Konser Sastra di Aula Fakultas Ilmu Budaya UHO, Sabtu, 4 Mei 2019. Konser tersebut mengusung tema "Berkarya dengan seni, eksis dalam sastra mencetus generasi langgas 4.0". Kegiatan konser dimaksudkan sebagai ajang mengembangkan kreativitas diri di bidang seni dan sastra bagi mahasiswa Sastra Indonesia angkatan 2016, 2017, dan 2018. Kegiatan yang digelar dalam konser itu antara lain unjuk teaterikal, pembacaan puisi, pembacaan prosa, musikalisasi puisi, dan tarian. Selain itu, 
mahasiswa sastra Indonesia pun mengadakan cipta puisi yang selanjutnya dibedah oleh dosen pengampu mata kuliah.

\section{Pementasan Drama}

Pentas drama yang dirangkaian dengan Buka Puasa Bersama HMPS Sastra Indonesia FIB UHO dilaksanakan pada tahun 2016 oleh Mahasiswa Sastra Indonesia angkatan 2014.

\section{Pameran Seni Rupa Sastra Indonesia Angkatan 2015}

Pameran Seni Rupa Sastra Indonesia tahun 2016 diisi dengan berbagai kegiatan. Selain pameran (seni lukis, seni patung, dan fotografi) acara juga diisi dengan pertunjukan sastra seperti musikalisasi puisi dan baca puisi. Pelaksana kegiatan ini adalah mahasiswa sastra Indonesia angkatan 2015, HMPS Sastra Indonesia FIB UHO, dan Sanggar Seni Katalis.

\section{Pentas Adu Kreasi}

Pentas Adu Kreasi digelar oleh Mahasiswa Sastra jurusan Pendidikan Bahasa Indonesia 2017 (25--29 April 2017). Salah satu lomba yang digelar ialah lomba menulis puisi yang mengangkat subtema lokalitas. Pesertanya adalah pelajar SMA dan sederajat, mahasiswa D1-S1. Pemenang mendapatkan hadiah berupa uang tunai. Naskah diterima selambat-lambatnya 25 April 2017.

\section{Pekan Lomba Kepenulisan}

Lomba Cipta Puisi dan Cipta Cerpen dalam rangka memperingati Hari Pahlawan 10 November. Peserta cipta puisi mengirim puisi minimal 1 halaman, peserta cipta cerpen mengirim karya 3 5 halaman.
HMJ Pendidikan Bahasa Indonesia, FKIP, Universitas Haluoleo (HMJPBI)

Himpunan mahasiswa jurusan bahasa aktif mengadakan aktivitas sastra baik aktivitas rutin maupun yang temporal. Aktivitas sastra yang termasuk kegiatan rutin dilaksanakan adalah Pekan Sastra Pendidikan Bahasa Indonesia 2017 dan 2019. Kegiatan lain yang dilaksanakan ialah seminar sastra, baca puisi, dan musikalisasi puisi. Berikut ini uraiannya.

\section{Pekan Sastra PBI 2017}

Pekan Sastra merupakan kegiatan yang rutin dilaksanakan oleh HMJ Pendidikan Bahasa FKIP Universitas Haluoleo. Kegiatan tersebut sebagai wujud kecintaan dan kebanggaan terhadap dunia sastra yang terus berkembang dan dinamis. Pekan Sastra PBI 2017 berlangsung 25-29 April 2017 mengusung "Tema junjung bahasaku, cintai sastraku, kenang penyairku". Pemilihan waktu pelaksanan pada bulan April berdasarkan asumsi bahwa banyaknya peristiwa kesasteraan yang terjadi sehingga bulan April diinsyafi sebagai tonggak lahirnya sastra modern dan progresif di Indonesia. Kegiatan yang digelar antara lain Cipta Puisi dan Cipta Cerpen. Lomba Cipta Puisi diperuntukkan untuk pelajar SMA dan sederajat, mahasiswa D1-S1. Tema puisi yang dipersyaratkan dalam Lomba Cipta Baca Puisi ialah lokalitas. Pemenangnya mendapatkan hadiah berupa uang tunai. Naskah diterima selambat-lambatnya 25 April 2017.

Dalam lomba baca puisi, panitia menyiapkan puisi wajib untuk Putra "Tangan Waktu" karya Sapardi Djoko Damono dan puisi wajib putri "Negeriku" karya K.H.A. Mustofa Bisri (Gus Mus). Puisi pilihan terdiri atas "Senja di Pelabuan Kecil" karya Chairil Anwar, 
"Baca Sajak Malam" karya Irianto Ibrahim, "Membaca Tanda-Tanda" karya Taufiq Ismail, "Kita Adalah Pemiliki Sah Republik Ini” karya Taufiq Ismail, "Kau Ini Bagaimana Atau Aku Harus Bagaimana" karya K.H.A. Mustafa Bisri (Gus Mus), "Kekasih Mata Langit" karya Sidin La Hoga, "Selamat Pagi Indonesia" karya Sapardi Djoko Damono. Pemenang baca puisi terdiri atas: Juara 1 Indri Ananda Hasanah (SMAN 2 Kendari); Juara 2 Isnar Alfadilah (SMAN 4 Kendari); Juara 3 Wa Ode Zahra Auliya (SMAN 4 Kendari). Selanjutnya, pada tanggal 25 April 2019 kembali menggelar beberapa kegiatan antara lain baca puisi, musikalisasi puisi, dan seminar sastra. Kegiatan ini bertujuan untuk menumbuhkan jiwa sastra di era milenial.

\section{Seminar Bulan Bahasa dan Sastra Nasional}

Seminar Bulan Bahasa dan Sastra Nasional digelar pada 28 Desember 2002. Agenda ini menjadi kegiatan rutin jurusan ini menghadirkan pemakalah lokal dan nasional. Sayangnya, hanya satu makalah tentang sastra dan selebihnya tentang bahasa dan pengajaran.

\section{Badan Pembina Seni Mahasiswa (BPSMI)}

Kegiatan Pekan Seni Mahasiswa Nasional merupakan salah satu kegiatan yang diselenggarakan oleh BPSMI. Peksiminas merupakan ajang kompetisi mahasiswa di bidang seni yang diselenggarakan oleh Kemenristekdikti bekerja sama dengan BPSMI. Peksiminas bertujuan untuk meningkatkan kualitas dan kemampuan praktik mahasiwa dalam menumbuhkan apresiasi terhadap seni, baik seni suara, seni pertunjukan, penulisan sastra, seni rupa, dan lain-lain. Pada tahun 2016 BPSMI Sulawesi Tenggara dipercaya menjadi penyelenggara Pekan Seni Mahasiswa Nasional 2016 (Peksiminas XIII). Tiga puluh satu perwakilan BPSMI dari 34 BPSMI se-Indonesia mengikuti berbagai cabang lomba yang digelar. Kegiatan sastra yang digelar dalam Peksiminas XIII meliputi monolog, penulisan puisi, dan cerpen.

Lomba monolog merupakan salah satu lomba dalam Peksiminas. Panitia menyediakan 10 judul naskah monolog. Pemain/peserta dapat memilih salah satu dari sepuluh naskah monolog yang sudah disediakan panitia, atau membawakan naskah sendiri yang terinspirasi dari naskah tradisi dengan catatan sudah dikirimkan minimal 3 bulan sebelum lomba kepada panitia. Durasi pementasan minimal 10 menit dan maksimal 15 menit pementasan di panggung. Kelengkapan panggung yang disediakan oleh panitia antara lain: level, kain hitam, tata cahaya, dan peralatan tata suara. Waktu setting panggung dan persiapan maksimal 10 (sepuluh) menit. Ilustrasi monolog bisa dalam bentuk musik live, rekaman kaset, atau CD, dan menggunakan bahasa Indonesia. Properti dan trik panggung harus memperhatikan keamanan dan keselamatan peserta lain. Penilaian keaktoran meliputi penghayatan, vokal, kelenturan, komunikatif, dan kerja sama. Penyutradaraan meliputi: interpretasi naskah, dan kesatuan. Penataan artistik: tata pentas, tata cahaya, tata suara, rias dan busana.

Salah satu monolog yang dipentaskan dalam Peksiminas XIII ialah monolog "Mayat Terhormat" yang dipentaskan oleh mahasiswa UGM. Monolog ini bercerita tentang seorang penjaga kuburan yang ingin menghormati mayat-mayat yang dibunuh secara tidak wajar, seperti diperluas atau dimutilasi. Mayat dibunuh akibat konflik suku, agama, ras, dan adat. Pesan yang ingin disampaikan dalam monolog itu adalah kita harus saling menghormati, 
menghargai, dan tidak membeda-bedakan umat manusia.

Persyaratan Lomba Monolog meliputi tema bebas asal tidak bertentangan dengan nilai dan etika bangsa Indonesia, materi disediakan (10 naskah monolog), gaya pementasan bebas, kostum pementasan bebas asal tidak bertentangan dengan nilai dan etika budaya bangsa Indonesia dan ketentuan umum, jumlah pemain satu orang.

\section{Forum Insan Seni Pertanian (FISTA)}

Forum Seni Pertanian merupakan komunitas yang bergerak dalam bidang seni dan sastra yang bernaung di bawah Fakultas Pertanian UHO. Beberapa aktivitas sastra yang pernah digelar FISTA adalah:

\section{Lomba Seni dan Pameran Hasil Karya (LENSA)}

Kegiatan Lomba Seni dan Pameran Hasil Karya (LENSA) berlangsung pada 8-9 November 2018 di Fakultas Pertanian. Kegiatan yang diikuti oleh anggota dari lembaga seni ini merupakan program kerja pengurus Fista 20172018.

\section{Pementasan Wajib Anggota Muda}

Kegiatan Pementasan Wajib Anggota Muda merupakan kegiatan rutin yang digelar untuk menyambut anggota baru dan salah satu syarat bagi anggota baru untuk dikukuhkan sebagai anggota tetap Fista. Tempat Pelaksanaan kegiatan setiap tahunnya berganti seperti Fista 2017-2018 berlangsung pada bulan Agustus di Taman Budaya Sulawesi Tenggara.

\section{Studio Apresiasi Insan Seni (Sains)}

SAINS merupakan sebuah organisasi kemahasiswaan yang berbasis di FKIP UHO serta bergerak di bidang kesenian dan kesusasteraan. Beberapa kegiatan yang pernah digelar adalah:

\section{Pentas Seni}

Kegiatan Pentas Seni bertema "Get Your Art with Sains" digelar oleh SAINS pada tanggal 12 Oktober 2017. Kegiatan dilaksanakan di Pelataran Fakultas Keguruan dan Ilmu Pendidikan (FKIP) UHO. Pementasan seni yang gelar antara lain tarian, puisi, menyanyi, stand up comedy, dan sebagainya. Kegiatan ini merupakan salah satu ajang promosi bagi SAINS untuk memperkenalkan SAINS kepada seluruh mahasiswa se-FKIP, khususnya mahasiswa baru. Sosialisasi SAINS dianggap penting untuk memotivasi mahasiswa agar mau bergabung dalam SAINS.

\section{Seminar dan Bedah Buku}

Bedah Buku novel Di Bawah Bayang-Bayang Wa Ode dan novel Savanah digelar pada tanggal 14 Februari 2017 di Sport Center UHO. Acara dihadiri oleh mahasiswa FKIP UHO. Dana bersumber dari penjualan tiket dan dana swadaya panitia.

\section{Pementasan Anggota pada Dies Natalis SAINS}

Pementasan berlangsung pada tanggal 15 Maret 2018 di Pelataran FKIP UHO. Kegiatan dimaksudkan untuk merayakan hari lahirnya SAINS sekaligus menjalin silaturahmi antaranggora SAINS dan mahasiswa.

\section{Unit Kegiatan Seni (UK-Seni) UHO}

Unit Kegiatan Seni Universitas Halu Oleo didirikan pada tanggal 9 September 1993 oleh beberapa seniman kampus, di antaranya Ir. L.M. Erawan Asman, Munawar Jibran, Arif, Faisal Husen, Drimulyo S., Haris Harahap, Djaharuddin, Takaryono, dan Mansyur Yusuf. 
Komunitas ini didirikan untuk menjadi wadah bagi mahasiswa untuk menyalurkan bakat dan minat dalam berkesenian. Arif terpilih menjadi Ketua UK Seni pertama. Selanjutnya, pada peroide 2009/2010 UK-Seni dipimpin oleh Krisma Ladae dari fakultas teknik. Berturut-turut UK-Seni dipimpin oleh Andi Ulul Azmi, Giant Prasetya, Rezky Wahyudi, Yusuf Kuswanto, dan Syamsiar Alam. Aktivitas sastra yang pernah digelar komunitas ini adalah:

a) Pekan Seni (lomba baca puisi, lomba baca teater, lomba mendongeng, dan teater).

b) Pementasan Seni Akhir Tahun (PESAN).

Kegiatan yang digelar pada tanggal 31 Desember 2002 menampilkan berbagai acara, seperti pembacaan puisi, teaterikal, dan monolog.

c) Pekan Olah Raga dan Seni antar Fakultas (PORSIAF).

Pekan Olah Raga dan Seni antar Fakultas (PORSIAF) merupakan kegiatan tahunan yang dilaksanakan oleh UK-Seni. Kegiatan yang dilaksanakan dalam PORSIAF meliputi kegiatan olah raga, seni, dan Ilmiah. Kegiatan ini diikuti oleh mahasiswa dari berbagai fakultas. Tujuannya untuk mencari minat dan bakat. Pemenang kegiatan direkomendasikan untuk mewakili universitas ke tingkat nasional. Tahun 2009 PORSIAF menggelar lomba membaca cerpen tingkat universitas.

Pada tahun 2019 acara Porsiaf dilaksanakan pada tanggal 6-8 November 2019. Acara yang diketuai oleh Samriah dan sekretarisnya Resti Amelia digelar Auditorium Mokodompit UHO. Peserta yang terlibat dalam berbagai lomba berjumlah 64 orang. Kegiatan ini bertujuan: (1) meningkatkan kegiatan ekstrakurikuler kemahasiswaan melalui minat, bakat, dan kemampuan mahasiswa khususnya di bidang seni; (2) meningkatkan dan mengembangkan apresiasi seni di kalangan mahasiswa untuk mengembangkan budaya lokal Sulawesi Tenggara; (3) Membina silaturahmi antarmahasiswa, khususnya di kalangan pekerja seni kampus serta mengembangkan minat, bakat, dan kreativitas untuk mencintai dan memahami seni sehingga melahirkan bibit-bibit baru yang kreatif dan imajinatif dalam dunia seni.

\section{Program Studi Sastra Inggris UHO}

Kegiatan yang digelar oleh Program Studi Sastra Inggris adalah Pagelaran Puisi "Say It with Poem". Kegiatan ini digagas oleh Israfyan Sofian selaku dosen pengampu mata kuliah Poetry. Kegiatan ini bertujuan untuk menggali potensi mahasiswa dan sebagai ruang aktualisasi seni dan apresiasi terhadap sastra, khususnya puisi berbahasa Inggris.

Pagelaran Puisi "Say It with Poem" diselenggarakan oleh Program Studi Sastra Inggris pada tanggal 25 November 2017 yang tempat di RUPA (Rumah Ilmu Pengetahuan). Peserta yang terlibat adalah mahasiswa Sastra Inggris angkatan 2015. Kepanitiaan terdiri atas dosen-dosen Sastra Inggris. Kegiatan yang diselenggarakan oleh Program Studi Sastra Inggris UHO ini mengangkat tema "Say it with Poem", yang artinya "Ungkapkan Lewat Puisi". Kegiatan ini merupakan kegiatan yang pertama kali diselenggarakan oleh program studi tersebut dan diharapkan sebagai penggerak dari pagelaran-pagelaran selanjutnya.

UK-Seni UHO menjadi sebuah komunitas yang cukup berperan bagi kegiatan seni, juga sastra di kampus. Walaupun sifatnya sebagai lembaga koordinasi seni, UK-Seni UHO juga aktif berkegiatan, yaitu di ranah sastra dengan pembacaan puisi, penulisan puisi, pementasan drama, dan diskusi sastra. 


\section{Aktivitas Sastra dalam Perspektif Bourdieu}

Terdapat 13 komunitas sastra yang menjadikan Kampus Universitas Haluoleo sebagai arena aktivitas sastra. Para agen mengejewantahkan gagasan terbaik mereka agar memberikan pengaruh di dalam jagat sastra kampus, khsususnya di Universitas Haluoleo. Sebagian besar komunitas tersebut dilahirkan oleh mahasiswa dan menjadi medan kreatif mahasiswa di ranah sastra. Kampus sebagai arena sastra menjadi medan yang nyata dan tempat terjadinya perjuangan mencapai prestasi sastra.

Ada kesamaan habitus sebagai sumber gagasan yang menjadi benang merah bagi adanya aktivitas sastra yakni memproyeksikan kegiatan sastra dalam bentuk seminar sebagai bukti konkret dari modal sosial, modal kapital, modal budaya, dan modal simbolik sekaligus.

Terdapat pula kesamaan produk sastra dari empat komunitas yakni Studio Drama, Sanggar BSI, Laskar Sastra, dan Pekerja Puisi Sultra yakni menerbitkan adanya penerbitan. Studi Drama menerbitkan antologi puisi antologi Bersama Memberi Harga pada Kata; Kumpulan Sajak Mengenang Chairil Anwar (2007) yang memuat karya penyair Kendari di antaranya karya Ahid Hidayat, Syaifuddin Gani, Subur, Adhy Rical. Sanggar BSI menerbitkan Buletin $B S I$ yang di dalamnya terdapat karya puisi dan cerpen, antara lain Didit Masrshel, Ruslan Manan, Abd. Razak Abadi, Adhy Lana, Irianto Ibrahim, Ipang de la Sora, Syaifuddin, dan Sumiman Udu. Laskar Sastra pun menerbitkan antologi puisi para anggotanya yakni Tak Ada Mata (Hari) terbit tahun 2018 yang memuat penyair Nur Afnia Asfar, Ahmad Ridwan Wanderer, Ade Nsf Ananda, Iddianto, Elda Haltita, Heni Ardagarini, Muhamad Nadzir, Zaenal Untung, Anandataff, Irna Yanti Pratiwi, Mashun
Low, Syamsul Mubarak, Indah Permata, Cicka Vaulia, dan Ace Nirwana. Pekerja Puisi Sultra (Eksis) pernah menerbitkan secara terbatas antologi puisi Barzanji di Tengah Karang karya pendirinya, Irianto Ibrahim. Para agen keempat komunitas ini memiliki visi budaya yang sama bahwa sastra harus memiliki media publikasi demi meraih modal yang lain, yakni modal sosial dan modal kapital. Di sini berkelindan antara modal kapital dan modal simbolik.

Karya sastra ini merupakan tonggak-tonggak bagi dunia kepenyairan di Kampus Universitas Halu Oleo yang dicapai karena adanya habitus yang terpercaya dari para agen, dan juga keberhasilan di dalam menerapkan beragam modal; budaya, sosial, ekonomi, dan simbolik. Arena sastra menjadi ruang eksistensi sekaligus ruang menjalin relasi. Arena merupakan sistem relasional atau di dalamnya terdapat berbagai kaitan antargen sehingga dengan demikian berpikir dalam kerangka tersebut tidak lain merupakan bentuk berpikir yang bersifat relasional. Aktivitas sastra di kampus pada akhirnya tidak tunggal, tetapi saling terkait. Mereka justru terhubung satu sama lain dan saling memengaruhi.

Di ranah Studio Drama, sebagai agen, Ahid Hidayat menjadikannya sebagai arena dan ruang sosial bagi ideidenya dalam menyelenggarakan peristiwa sastra dan kesenian. Ia mampu meyakinkan mahasiswa, sastrawan, dan seniman bahwa komunitas yang didirikannya bertujuan membawa sastra ke muruah yang layak diberi tempat. Habitus sastra yang merupakan representasi pemikirannya diujudkan dalam agenda seni yang menjadi perbincangan. Posisinya sebagai dosen sastra dan pengamat sastra serta kesenian di Kota Kendari menjadi modal sosial, modal budaya, dan simbolik sekaligus. Itulah sebabnya, walaupun tidak dalam 
masa panjang mengelola Studio Drama, tetapi ia berhasil menjadikannya sebagai arena aktivitas sastra yang menyita perhatian. Banyak sastrawan dan seniman luar kampus yang diajak dalam program kesenian di Studio Drama. Modal simboliknya sebagai pengamat seni memainkan peran tersendiri dalam aktivitasnya. Habitus yang berada dalam pikiran sang agen secara sadar juga dipengarahi oleh arena yang membentuk pemikirannya.

BSI telah menjadi arena dan ruang sosial yang patut diperhitungkan di lingkungan kesenian kampus dalam masa 1999-2002. Waktu yang cukup singkat ini menjadi arena yang cukup dinamis di dalam menyelenggarakan agenda sastra. Di sini, salah satu agen atau aktornya adalah Abdul Razak Abadi (Adhy Rical) yang mampu menegosiasikan agen lainnya dalam sistem manajemen organisasi yang ia terapkan. Modal ekonomi yang dimiliki Adhy Rical yang lebih mapan dibanding agen lainnya, sekaligus menjadi modal budaya di dalam mengelola sumber daya sesama anggota BSI, yang beberapa di antaranya adalah anggota Teater Sendri Kendari.

Pentas seni menjadi modal budaya sangat penting di mayoritas komunitas sastra kampus seperti Bengkel Seni Fisip, Eksis, Katalis, Laskar Sastra, Himpunan Mahasiswa Sastra Indonesia, HMJ Pendidikan Bahasa Indonesia, FISTA, dan UK Seni UHO. Dengan beragam agenda seni seperti pemtas teater, musikalisasi puisi, konser musik, pergelaran sastra, konser sastra, dan pentas adu kreasi. Hal mendasar dari fakta ini ialah bahwa hubungan antarpelaku aktivitas sastra dalam arena berkesenian di kampus tersebut, kapital dan budaya merupakan faktor determinan di dalam mengafirmasi agenda-agenda sastra dimaksud.

Pernyataan bahwa produksi sastra merupakan salah satu arena perebutan pengaruh oleh para aktor atau agennya dalam mencapai tujuannya untuk mencapai pengakuan, yaitu siapa yang akan dianggap sebagai pemilik salah satu posisi dalam area sastra tersebut, benar adanya dalam konteks aktivitas sastra di Kampus Universitas Halu Oleo. Begitu banyak komunitas sastra di kampus yang eksis. Aakan tetapi, jika melihat aktivitas sastranya, Laskas Sastra (Lastra) memperlihatkan usia panjang berkegiatan. Ia didirikan sejak 2006 dan sampai 2021 ini tetap solid karena regenerasi anggota yang terus terjadi yang berkorelasi dengan masuknya mahasiswa baru di Universitas Haluoleo sebagai ladang keanggotaan. Berdeda dengan dengan Sanggar BSI dan Eksis yang "bubar" ketika pengurusnya menjadi alumni, Lastra berhasil menguatkan modal budaya dan modal sosial yang dimilikinya sehingga terus mendapat kepercayan di kampus. Hubungan baiknya dengan dosen dan birokrasi kampus menjadi modal sosial yang baik untuk meraih prestasi. Ajang lomba cipta puisi yang diadakan setiap tahun menjadi modal budaya untuk menguatkan posisinya sebagai sanggar sastra yang berpengaruh di kampus.

Salah satu kekhasan komunitas sastra di kampus ialah adanya seminar sastra atau budaya. Ini tampak pada Sanggar Katalis, Lastra, dan HMJ Pendudukan Bahasa Indonesia-FKIP.

Posisi UK-Seni UHO sebagai organisasi seni yang ada di tataran universitas memainkan dan menciptakan arena sastra yang cukup penting. UKSeni UHIO adalah penyelenggara Pekan Olah Raga dan Seni Antar Fakultas (PORSIAF) yang digelar setiap tahun. Sebagai perpanjangan tangan pihak universitas dalam ajang seni kampus, UK-Seni UHO menjadi pusat arena sastra yang menyajikakan beragam kegiatan seni, seperti lomba baca puisi, lomba cipta puisi, lomba mendongeng, dan 
teater. Modal kapital dan modal sosial yang dimilikinya menjadi faktor penentu tersendiri di dalam penyelenggaraan kegiatannya. Pengerahan atau dialektika habitus dan aneka modal itu merupakan ujud perjuangan dalam arena. Untuk sekadar menyebut nama, beberapa agen/actor di UK-Seni UHO yang cukup berperan adalah Munawar Djibran, Asidin La Hoga, Irfan Ido, Amin Udo, dan Harnika.

Selain sastra dan pentas seni secara umum, ranah lain yang juga cukup sengit dinamikanya di Kampus Universitas Halu Oleo ialah pentas teater. Hampir tidak ada komunitas yang tidak pernah mementaskan teater, baik di ranah Kampus Universitas Halu Oleo itu sendiri maupun di luar kampus, bahkan ke perhelatan nasional. Sanggar BSI dan UK-Seni UHO menjadi dua komunitas kampus yang sering mewakili kampusnya dalam perhelatan teater di tataran nasional. Relasi sosial, modal budaya, dan modal simbolik menjadi faktor determinan dalam menancapkan nama komunitas dan Kampus Universitas Halu Oleo dalam jagat perteateran di luar.

Dari paparan tersebut dapatlah dikatakan bahwa arena merupakan medan perjuangan bagi semua subjek atau sang aktor/agen guna menentukan siapa yang menjadi bagian dari semesta perputaran aktivitas sastra di Kampus Universitas Halu Oleo.

\section{Kendala dalam Pelaksanaan Aktivitas Sastra di Kampus}

Kendala yang dihadapi oleh komunitas dalam menyelenggarakan aktivitas sastra sering berkaitan dengan pendanaan, peralatan latihan, alat untuk pementasan, dan sumber daya manusia. Pendanaan merupakan hal yang krusial karena sebuah kegiatan sulit terlaksana tanpa ketersediaan dana. Solusi yang kerap ditempuh oleh komunitas dalam menghadapi masalah dana adalah dengan menarik iuran anggota, menggelar kegiatan bazar, dan menarik kontribusi dari peserta kegiatan. Untuk masalah sumber daya manusia, setiap komunitas giat melakukan perekrutan, pengaderan, dan pembinaan anggota.

Selain itu, keberadaan sekertariat pun masih menjadi kendala sebagian komunitas. Ada komunitas yang belum memiliki sekertariat sehingga masih sering menumpang di tempat lain yang masih terbatas pemakaiannya. Dengan tidak adanya studio sendiri, latihan pun menjadi sulit dilakukan. Itu artinya, perlu upaya lebih giat lagi untuk mengoptimalkan potensi modal; modal ekonomi, modal sosial, modal budaya, dan modal simbolik. Tidak kalah pentingnya adalah peran habitus dari para agen serta laku kesusastraan dalam arena kesenian kampus perlu dimaksimalkan potensinya.

Teori Bourdieu menegaskan bahwa di dalam arena, kedudukan manusia tidak ditentukan oleh pengelompokkan berdasarkan kelas. Akan tetapi, kedudukan pribadi atau individu di dalam ruang sosial itu ditentukan oleh kepemilikan modal atau kapital dalam berbagai macam bentuk, terutama sebagai modal sosial, modal ekonomi, dan modal budaya untuk diakumulasikan dan dimaksimalkan. Pandangan tersebut memang memiliki relevansi yang kuat pada dinamika aktivitas sastra di Kampus Universitas Halu Oleo, Kendari.

\section{PENUTUP}

Berdasarkan pembahasan yang telah dilakukan dalam penelitian ini dapat simpulkan dalam beberapa bagian berikut. Penyelenggara aktivitas sastra di kampus UHO Kendari adalah komunitas yang bergerak dalam bidang seni, sastra, dan budaya. Komunitas seperti Studio Drama, Bengkel Seni Fisip (Benfis), 
Pekerja Seni (Eksis), Bengkel Seni Indonesia (BSI) UHO, Sanggar Katalis, Laskar Sastra (Lastra), Himpunan Mahasiswa Pendidikan Bahasa Indonesia (HMPBI), Himpunan Mahasiswa Sastra Indonesia (HMSI), Forum Insan Seni Pertanian (Fista), SAINS, Unit Kegiatan Seni (UK Seni) UHO, dan Program Studi Bahasa Inggris merupakan komunitas penyelenggara aktivitas sastra di UHO. Habitus dan aneka modal mereka pergunakan sebaik mungkin di dalam aktivitas sastra. Aktivitas sastra yang sering digelar di kampus UHO Kendari meliputi pembacaan puisi, pembacaan cerpen, aksi teaterikal, monolog, pementasan drama, penulisan puisi, penulisan cerpen, penerbitan antologi puisi, seminar sastra, bedah buku, musikalisasi puisi, dan sebagainya. Aktivitas itu lahir dari arena yang merupakan sistem relasional yang di dalamnya terdapat berbagai kaitan antaragen. Agen ini adalah para mahasiswa yang menggerakkan aktivitas sastra. Tujuan pelaksanaan aktivitas sastra di kampus adalah sebagai wadah penyaluran bakat dan minat seni dan sastra mahasiswa dan menumbuhkan kecintaan dan apresiasi sastra masyarakat khususnya mahasiswa. Apresiasi tersebut lahir dari adanya praktik nyata dari mahasiswa sebagai agen. Praktik itu terbentuk dari berjalannya hubungan yang saling mendukung dan bersifat saling balas/dialektis antara sutruktur dan aktor/agen.

Dengan merujuk hasil penelitian, berikut beberapa saran dari peneliti. Pertama, pengelola komunitas perlu memperbaiki manajemen pengelolaan administrasi dalam komunitas agar semua kegiatan dapat terdokumentasi dengan baik; dan kedua bahwa pemangku kebijakan perlu memberikan penguatan dengan mengadakan kegiatan peningkatan pengelola komunitas sastra di kampus.

\section{DAFTAR PUSTAKA}

Barlian. (2010). Gerakan mahasiswa di Kendari Sulawesi Tenggara. Universitas Negeri Makassar.

Bourdieu, P. (1993). The field of cultural production: Essays on art and literature. In R. Johnson (Ed.), Columbia University Press. New York City: Columbia University Press.

Damono, S. D. (1979). Sosiologi sastra: Sebuah pengantar ringkas. Jakarta: Pusat Pengembangan dan Pembinaan Bahasa.

Devi, R. (2010). Perjuangan simbolik seorang ilmuwan sebagai ayah alternatif pada novel Hakase No Aishita Suushiki karya Ogawa Yoko. Universitas Indonesia.

Hartanto, E. C. S. (2011). Perjuangan tokoh Balram Halwai sebagai bentuk kritik terhadap ketidakadilan kasta di India dalam novel The White Tiger karya Aravind Adiga. Universitas Indonesia.

Hidayat, Ahid, Rahmania, dan U. (2004). Komunitas sastra di Sulawesi Tenggara.

Manuaba, I. B. P. (2019). Komunitas sastra, produksi karya, dan pembangunan karakter. Mozaik Humaniora, 19(1), 37-47.

Nilofar, N. (2016). Arena produksi kultural Komunitas Pelangi Sastra Malang. Alayasastra, 16(1), 119133.

Rafida, U., Sarengindeyati, E. dan A. T. (2013).

Rafida,

U., Sarengindeyati, E. dan Ampera T. Aplikasi Ipteks Untuk Masyarakat., Volume 2 N, 51--59.

Ratna, N. K. (2013). Teori, metode, dan teknik penelitian sastra. Yogyakarta: Pustaka Pelajar. 
Ritzer, G., \& Goodman, D. J. (2005). Teori sosiologi modern (6th ed.). Jakarta: Prenada Media.

Rohinah M. Noor. (2012). The curriculum: Membangun karakter melalui kegiatan ekstrakurikuler. Yogyakarta.

Salam, A., \& Anwar, S. (2015). Strategi dan legitimasi komunitas sastra di Yogyakarta: Kajian Sosiologi Sastra Pierre Bourdieu. Widyaparwa, 43(1), 25-38.

Sarumpaet, R. K. T. (2010). Pedoman

Sayotte. (2010). Kegiatan ekstrakurikuler.

Sofian, N. I. (2017). Model pewarisan cerita rakyat melalui story telling. Bastra, Vol.2 No.5, 1--15.

Teeuw, A. (2015). Sastra dan ilmu sastra: Pengantar teori sastra. Bandung: Dunia Pustaka Jaya.

Wellek, R. dan A. W. (1993). Teori kesusasteraan (Diterjemahkan oleh Melani Budianta). Jakarta: Gramedia Pustaka Utama. Yayasan Pustaka Obor Indonesia. 